\title{
THE FEMALE SELF AS PRESENTED BY CLARISSA PINKOLA ESTÉS IN WOMEN WHO RUN WITH THE WOLVES. THE STORIES OF FEMALE INITIATION, INTUITION AND INSTINCTS
}

\section{KOBIECE „JA" W UJĘCIU CLARISSY PINKOLI ESTÉS W BIEGNĄCEJ Z WILKAMI. OPOWIEŚCI O KOBIECEJ INICJACJI, INTUICJI I INSTYNKCIE}

\author{
Marta Popławska ${ }^{1(\mathrm{~A}, \mathrm{~B}, \mathrm{C}, \mathrm{D}, \mathrm{E}, \mathrm{E}, \mathrm{G})}$ \\ ${ }^{1}$ Państwowa Szkoła Wyższa im. Papieża Jana Pawła II w Białej Podlaskiej, Zakład Neofilologii
}

Popławska, M. (2018). The female self as presented by Clarissa Pinkola Estés in Women Who Run With the Wolves. The stories of female initiation, intuition and instincts. Rozprawy Społeczne, 12(3), 14-19. https://doi.org/10.29316/rs.2018.28

Wkład autorów:

A. Zaplanowanie badań

B. Zebranie danych

C. Dane - analiza i statystyki

D. Interpretacja danych

E. Przygotowanie artykułu

F. Wyszukiwanie i analiza

literatury

G. Zebranie funduszy

Tabele: 0

Ryciny: 0

Literatura: 11

Otrzymano: marzec 2017

Zaakceptowano: maj 2017

\section{Introduction}

In her work entitled Women Who Run With the Wolves, Clarissa Pinkola Estés examines myths, tales and legends of various cultural and ethnic backgrounds to elicit the wild woman archetype. Her interpretations of the stories, which serve to retrieve and understand the complexities of women's nature, seem to depict the universalities of the female self that appears in different forms and shapes in many cultures. The following paper focuses on three essential elements of the female self, namely initiation, intuition and instincts as presented in three tales recounted in the book, that is the story of Bluebeard, the story of Vasilisa the Wise and the story of the Red Shoes. The aim of the article is to present Estés's interpretations and her vision of the female self as well as to confront her readings with other existing analyses of the tales. Although Estés's work is mainly considered to be a self-help book instructing and empowering women to get close to their true nature, it is also evident that it can serve as a source of cultural knowledge and inspire further literary analyses.

In her work Estés applies the methods of archetype analysis consistent with Jungian psychoanalytic approach and compares the wild woman archetype with images appearing in tales and myths. Jung describes archetypes as "a kind of structure of the primary images of unconscious collective fantasies", or "structural elements of the unconscious psyche that give rise to myths" (Meletinsky, 1998, p. 44). Although his approach has been criticised for its "lack of precision about

Adres korespondencyjny: Marta Popławska, Państwowa Szkoła Wyższa im. Papieża Jana Pawła II w Białej Podlaskiej, Zakład Neofilologii, ul. Sidorska 102, 21-500 Biała Podlaska, e-mail: m.poplawska@dydaktyka.pswbp.pl, tel.: 833449900 Copyright by: Państwowa Szkoła Wyższa im. Papieża Jana Pawła II w Białej Podlaskiej, Marta Popławska

Czasopismo Open Access, wszystkie artykuły udostępniane są na mocy licencji Creative Commons Uznanie autorstwa-użycie niekomercyjne-na tych samych warunkach 4.0 Międzynarodowe (CC BY-NC-SA 4.0, http://creativecommons.org/licenses/by-nc-sa/4.0/). 
the nature of the relationship between myth and archetype" (Meletynsky, 1998, p. 45) which leads some scholars to consider every image a myth, or for its ignorance of the social aspects of myths and legends in favour of the psychological dimension, it cannot be denied that it allows us to reconsider our attitude to myths, legends and folktales and appreciate their value as meaning-bearing cultural artefacts. Drawing from Jung's theories, Estés rediscovers the richness of narrative folklore and its universal meaning for the modern woman.

\section{Bluebeard}

The first tale recounted by Estés to be discussed is the story of Bluebeard, which is a well-known folktale whose different versions can be found in many cultures but whose first written version was published by Charles Perrault in 1697 (Zipes, 2007). In short, it is a story of a noble man who in spite of his obvious monstrosity, in the story depicted in the form of his awe-inspiring ugly blue beard, succeeds in persuading a young girl to marry him. One day prior to his departure, Bluebeard encourages his young wife to enjoy herself in his mansion and do whatever she desires to on condition that she does not open the door of a certain forbidden room. During his absence, however, the young wife disobeys her husband's order and, urged by her older sisters, walks into the mysterious chamber, discovering Bluebeard's secret. The room is filled with bloody corpses of his previous wives. Horrified and determined to avoid the fate of her predecessors, the girl tries to obliterate the traces of her visit to the room by hiding the key, which got stained and started to bleed. Bluebeard, shown as a cunning predator, soon learns about the young wife's misbehaviour and wants to murder her. He is, however, prevented by the girl's brothers who manage to rescue her in time and kill Bluebeard (Estés, 1995).

Undeniably, there are multiple interpretations of the story and, what is more, it is noticed by critics that the versions appearing in different traditions leave the reader with completely different impressions - the Italian and the English versions produce humorous effects, the German versions are horrific and the French seem dramatic (Hermansson, 2009). Traditionally, however, the tale's interpretations follow Perrault's moral to the story and revolve around the theme of "the evils of female curiosity" (Zipes, 2000,p.56), depicted in the figure of theyoung wife who cannot resist the temptation to enter the forbidden chamber. As Tatar points out, "in his moral to the story, Perrault aligns the intellectual curiosity of Bluebeard's wife with the sexual curiosity of women in general, thus hinting that his protagonist is very much a daughter of Eve. By underscoring the heroine's kinship with certain literary, biblical, and mythical figures (most notably Psyche, Eve, and Pandora), Perrault gives us a tale that willfully undermines a robust folkloric tradition in which the heroine is a resourceful agent of her own salvation. Rather than celebrating the courage and wisdom of Bluebeard's wife in discovering the dreadful truth about her husband's murderous deeds, Perrault and many other tellers of the tale disparage her unruly act of insubordination." (Tatar, 2002, p. 147) Apart from the theme of knowledge acquisition, other possible interpretations include taboos surrounding the acquisition of wealth and high social status by a woman or depicting irrational male evil. Freudian interpretations focus on sexuality where "the key is phallic, while the lock into which it is inserted and the forbidden chamber are both vaginal" (Hermansson, 2009 , p. XV). Scholars also focus on the wife's transgression interpreted as sexual infidelity and the following punishment as the husband's right to execute his unfaithful wife practised in some cultures. Feminist readings of the tale suggest that the fact that Bluebeard's wives are slain for looking into the forbidden chamber is a warning for women against becoming excessively acquainted with their own bodies. Furthermore, postmodern feminists see the chamber as representing History, particularly the history of male physical and sexual violence inflicted on women with the support of culture (Hermansson, 2009). All in all, the most elemental interpretations centre around a prohibition and its transgression, and Bluebeard's wife is seen as "a fairy tale representation of the archetype of female transgressive curiosity" (Hermansson, 2009, p. 15).

Estés's interpretation is consistent with Jungian psychoanalysis in which "the conflict between Bluebeard and his wife is between two warring aspects of the psyche, reconciliation of which is necessary to individuation" (Hermansson, 2009, p. XVI). Individuation is a term used by Jung to describe "the process of personality development which leads to the fullest possible actualization of the Self. Individuation means becoming a single, homogeneous being, and, in so far as 'individuality' embraces our innermost, last, and incomparable uniqueness, it also implies becoming one's own self. We could therefore translate individuation as 'coming to selfhood' or 'self-realization'" (Stevens, 2002, p. 354). Since it plays a vital role in the development of the self, it is not surprising that individuation is perceived as one of the most fundamental archetypes appearing in Jungian analytical psychology and is said to occur in the majority of folk tales (Gary, El Shamy, 2005). Therefore for Estés, the Bluebeard tale is about the captor, or the innate predator who resides in all women's psyches, who represents an "against nature" force which prevents development, disrupts harmony and "acts in opposition to the instincts of the natural Self" (Estés, 1995, p. 45). According to Estés, every woman should be aware of the predator's existence and the knowledge is essential for her to become a mature creature "who 
is not vulnerable out of naiveté, inexperience or foolishness" (Estés, 1995, p. 45).

Generally speaking, Estés reads Bluebeard as a story of early initiation where a young naïve woman meets the destructive force, the predator and falls prey to his powers and a cunning game, yet, she discovers the way to reveal the secret and defeat the monster. The author's first question concerns the reasons for the girl's decision to marry the monster. It seems that having been trained all her life 'to be nice,' the girl disregards her intuition and ignores the danger connected with Bluebeard's monstrosity. Estés calls it "Bluebeardian mesmerisation" and explains it as follows: "When the youthful spirit marries the predator (...) instead of living freely, she begins to live falsely. The deceitful promise of the predator is that the woman will become a queen in some way, when in fact her murder is being planned. (...) He prompts the woman to feel a false sense of freedom. He implies she is free to nourish herself and to revel in bucolic landscapes, at least within the confines of his territory. But in reality, she is not free, for she is constrained from registering the sinister knowledge about the predator" (Estés, 1995, p. 51). However, in order to begin and complete this early initiation, the girl must disobey Bluebeard's order, use the key and open the forbidden door, thus revealing the truth about the monster-husband. The key which opens the forbidden door is an important element of Estés's interpretation. In its most basic meaning it symbolises entry into knowledge, here it is the knowledge that cannot be ignored or forgotten since the key gets stained with blood which is impossible to be removed. Additionally, in Estés's version of the tale, the key becomes a telltale sign of the wife's transgression as it starts to bleed. For Estés opening the door is like awakening and the knowledge it brings is an essential step in forming a mature conscious female self. The corpses of beheaded wives can be thus read as "lifeless thoughts and feelings and desires; ones which were once graceful and promising but now are drained of blood" (Estés, 1995, p. 53). Estés seems to point to the fact that women fall victim to inner forces such as complexes or addictions which blind them, limit their hopes, block their dreams and impede the process of individuation. Yet, by retelling the story that depicts an inexperienced girl who is able to break the imposed restriction, identify the predator and eventually defeat him, Estés points to the possibility of change which stimulates proper development.

Jungian psychology, however, does not seem to be the only factor influencing Estés's tale analyses. In the introduction to Women Who Run With the Wolves she writes: "My own post-World War II generation grew up in a time when women were infantilized and treated as property. (...) Dancing was barely tolerated, if at all, so they danced in the forest where no one could see them, or in the basement, or on the way out to empty the trash. Self-decoration caused suspicion. Joyful body or dress increased the danger of being harmed or sexually assaulted" (Estés, 1995, p. 3). The vision of women constrained and belittled by the culture they live in is not alien to the author and it appears that her experiences as a woman brought about a feminist-oriented approach with special sensitivity to the issues of female empowerment, limited access to knowledge or wisdom, inadequate possibilities of development as well as undervalued, misunderstood or simply forgotten natural instincts and powers essential for the maturity of the female self. Thus, it should be noted that the destructive force of Bluebeard constraining the woman is also seen as the one that comes from the outside and takes the form of a peer group, oppressive culture, religion, family or husband (Estés, 1995). Furthermore, just as Tatar, who points out that many critics including Bettelheim "turn a tale depicting the most brutal kind of serial murders into a story about idle female curiosity and duplicity" (Tatar, 1987, p. 161), Estés also notices that "women's curiosity was given quite a negative connotation, whereas men with the same attribute were called investigative. Women were called nosy, whereas man where called inquiring" (Estés, 1995, p. 51). Furthermore, for Estés the trivialization of female curiosity equals denying women's intuitions while "asking the proper questions is the central action of transformation - in fairy tales, in analysis, in individuation" (Estés, 1995, p. 52).

\section{Vasilisa the Wise}

Another tale recounted by Estés is the story of Vasilisa the Wise, which is also a tale of initiation, although, this time it is a fuller initiation in which intuition plays a crucial role. Vasilisa, the main heroine, is called the Wise by Estés, but in other versions she is also known as Vasilisa the Fair or Vasilisa the Beautiful. The story belongs to Russian folklore and its most famous version was written by Alexander Afanasev (Tatar, 2002). Vasilisa is a girl who becomes a half-orphan and has to struggle with various adversities including a jealous and spiteful stepmother and her daughters. Before her death however, Vasilisa's mother gives her a doll asking the girl to look after her, feed her and give her something to drink in return for help and protection. When the father remarries, Vasilisa suffers injustice and discrimination on the part of her step-family, who hate the beautiful and hardworking girl. One day, during the father's absence, the stepmother forces Vasilisa to go to the woods to Baba Yaga to fetch some fire. The obedient girl, although frightened, sets off and soon arrives at the witch's horrifying house, which is made of human bones and walking on chicken legs. Vasilisa, being exposed to death threats, becomes, in a sense, enslaved by Baba Yaga who forces the girl to carry out various household chores including cleaning the house, cooking meals, doing the laundry or the 
almost impossible task of separating poppy seeds from specks of dirt. All the time, Vasilisa is given advice and support by the little doll she carries with her, which is one of the reasons why she finally gets the fire from Baba Yaga and manages to avoid death. She is even rewarded for her courage, as after she returns home happily the fire she brings from the witch burns the stepmother and her daughters. They die in flames giving Vasilisa freedom from persecution. In some versions of the tale, although not in the one recounted by Estés, in the end Vasilisa also marries the tsar who is impressed with the girl and her skills (Estés, 1995).

Generally, it seems valid to state that the tale follows the sequence of events as discerned by Vladimir Propp. Zipes summarizes it as follows: "the initiation of a young man or woman that takes the form of a quest; and the visit to the land of the dead and regeneration. In the first sequence, the hero/ine of almost all wonder tales is an initiate who lacks something, must abandon or is banished from home, receives help in the form of advice or magical objects from a donor or donors (a witch, wise woman, or hermit), is tested, and either happily survives or dies." (Zipes, 2012, p. 66) Traditionally, the tale's interpretations focus on the theme of female obedience, industriousness and family conflicts. Zipes draws our attention to the way the main female protagonists are presented in fairy tales, and Vasilisa appears to be one of them. He comments as follows: "Witches and fairies are not the only significant female characters in fairy tales. In fact, beautiful innocent maidens may be more important, but in the hands of male tellers, writers, and collectors, they tend to be depicted as helpless, if not passive. To be good, they must be obedient and industrious. The overwhelming number of oral and literary fairy tales up through the nineteenth century usually stereotype the young heroine (...) . It is because of a more general patriarchal view of women as domestics and breeders, born to serve the interests of men" (Zipes, 2012, p. 80). This claim seems to be consistent with what Tatar points out, that is "the story of Vasilisa reflects the cultural values of an earlier age, of a time in which excellence in the household crafts was treasured as highly as beauty" (Tatar, 2002, p. 173). For Afanasev, on the other hand, who saw fairy tales as carriers of knowledge about the natural world for primitive people, the tale epitomised "a battle between sunlight (Vasilisa) and storm (the stepmother) and other dark clouds (the stepsisters)" (Tatar, 2002, p. 334). Critics also emphasize the significance of another female character of the story, that is Baba Yaga, who is one of the most popular figures appearing in Russian folklore and discussed by literary critics and scholars of other disciplines. She is described as "compelling and dreaded because she forces the protagonists to test themselves while not deluding themselves that there is an easy way to reconcile conflicts" (Zipes, 2012, p. 63).
Again, with her Jungian approach, Estés offers a different perspective in looking at the story of Vasilisa. She describes the theme of the tale as "the retrieval of intuition as initiation" (Estés, 1995, p. 76), intuition which is viewed as the treasure of the female self, "inner seeing, inner hearing, inner sensing and inner knowing" (Estés, 1995, p. 83). Estés writes: "Vasilisa is the story of handing down the blessing on women's power of intuition from mother to daughter, from one generation to the next" (Estés, 1995, p. 83.) Nevertheless, in order to gain intuition a woman must complete certain tasks which form the whole process of initiation. The first stage is letting the good mother die and accepting her legacy. Estés points to the importance of eliminating all the obstacles inhibiting women's development and maturity, one of them being an over-protective mother who prevents a girl from facing new challenges. In the story, it is only after her mother's death that Vasilisa confronts her fears and accepts to take up a challenge of meeting Baba Yaga. Yet, Vasilisa also accepts the mother's legacy, that is the doll. Tatar describes its function as follows: "Whereas Cinderella and her folkloric cousins usually receive assistance from nature (trees, fish, brooks) or from a fairy godmother, Vasilisa is given a cultural artefact, a figure that can be seen as a miniaturized version of herself or as a symbolic form of her mother. While the doll protects and helps Vasilisa, it is also something to be nurtured and cared for, thus strengthening the fact of her own agency in escaping from villainy at home" (Tatar, 2002, p. 174). For Estés, learning to listen to the doll means learning to listen to and rely on intuition, which she describes as "the voice of inner reason, inner knowing, inner consciousness" (Estés, 1995, p. 92).

The next step in the process of Vasilisa's initiation is facing Baba Yaga representing instinctive nature, the wild feminine as well as "the power of annihilation and the power of the life force at the same time" (Estés, 1995, p. 96). Estés draws our attention to the fact that Baba Yaga is fair and "does not hurt Vasilisa as long as Vasilisa affords her respect. Respect in the face of great power is a crucial lesson. A woman must be able to stand in the face of power, because ultimately some part of that power will become hers" (Estés, 1995, p. 96). Thus, all the tasks Vasilisa is forced to complete in the witch's house seem to bring her closer to her own instinctive nature and teach her how to look after her wildish self. When Vasilisa completes all the tasks successfully she finally gets what she came for - the fire. Estes comments on this part of the tale as follows: "When the Yaga gives Vasilisa a lighted skull, she is giving her an old-woman icon, an 'ancestral knower,' to carry with her for life. She is initiating her into matrilineal legacy of knowing” (Estés, 1995, p. 111). Here again apart from the conventional interpretation of the tale's moral, that is if you are good and polite, listen to the wise and 
use your own intuition you will be rewarded but if you are unkind and vicious, like the stepmother and her daughters, you may be duly punished, Estés offers us yet another feminist-oriented reading. She writes: "another way to strengthen connection to intuition is to refuse to allow anyone to repress your vivid energies... that means your opinions, your thoughts, your ideas, your values, your morals, your ideals" (Estés, 1995, p. 118). It appears then that Estés perceives the story as that of female liberation presenting the protagonist's passage from a subservient position to self-reliance and maturity.

\section{The Red Shoes}

The last tale to be analysed in this article is a tale of lost instincts entitled "The Red Shoes," originally written by Hans Christian Andersen in 1845 (Zipes, 2000). It is a story of a poor orphaned girl (in Andersen's version called Karen), who is adopted by a wealthy old lady. The woman takes the girl to her house and gives her everything she needs but expects her to be polite, well-mannered and obedient. Among many other things she is gifted with, the girl receives a pair of beautiful red shoes as a substitute for her old hand-made ragged red shoes. She is impressed by the shoes to such an extent that she ignores the old lady's order and wears the shoes to church on Sunday. One day she meets a strange-looking old soldier who comments on the girl's footwear. Soon after, her shoes start to move around and dance even against the girl's will. When the unhealthy fascination with the shoes fades away, the girl realises her mistake but it is too late. The shoes will not come off. Terrified and completely exhausted from this terrible dance, the girl finally decides to have her feet cut off. She learns a painful lesson as her life gets miserable after becoming disabled (Estés, 1995).

Although Estés's version of the tale differs in several details, especially as far as the ending is concerned (the author neglects Andersen's Christian motif of Karen going to heaven), the core and the traditionally interpreted moral of the story stay unchanged. It could be generally said that "The Red Shoes" tale revolves around the themes of vanity and selfishness (the girl seems blindly absorbed in the beauty of the red shoes), disobedience and conformity to social roles (when living with the old lady the heroine is expected to follow orders but she disregards the old lady's request not to wear the shoes to church) as well as social class aspirations (she acquires higher social status after being adopted by the rich old lady). Yet, it cannot be denied that the major symbol of the story, that is the red shoes, provokes multiple interpretations both positive and negative. As Davidson writes, "red shoes synthesize multiple and ambiguous cultural codes. The meanings and conflicts around the combination of a color and footwear are highly charged as a cultural marker. The color red represents life and fertility in European and Asian traditions, but it also has associations with danger, war and death. Red is the color of the extremes of humanity, strong emotions, magic and religious experiences. (...) The highest ranks of the Catholic Church wear red vestments, but it is also the color of red-light districts, scarlet women and the Devil. The ambivalence between love and war, magic and religion, nobility and vulgarity, creates fundamental tensions in the use of this color" (Davidson, 2006, p. 273). The shoes may be thus seen as manifesting passion and sexuality, and the unrestrained dance as a form of bodily expression, which could be, on the one hand, perceived as positive suggesting freedom and mobility, and on the other hand, inappropriate for a well-behaved girl and thus severely punished. It is noted by scholars that "Andersen's productive work takes place within a male social order, and Andersen seems to never tire of brutally punishing female figures for disrespecting its laws" (Zipes, 2007, p. 134). Clearly, Karen is portrayed as a "bad" female character who must do penance for her defiant behaviour. Interestingly, it is observed by some critics that "this association has proved to be an enduring cultural idea, with red shoes denoting women who transgress against acceptable feminine norms" (Davidson, 2006, p. 277).

Estés also criticises the harmful influence of restrictive society on women and her reading of the tale's major symbol is rather negative. The tale itself is seen by the author as a warning against various traps waiting for the wild female self which lead to the loss of natural instincts. Estés comments: "the loss of the hand-made red shoes represents the loss of a woman's self-designed life and passionate vitality, and the taking on of a too-tame life. This eventually leads to loss of accurate perception, which leads to excess, which leads to loss of feet, the platform on which we stand, our basis, a deep part of our instinctual nature that supports our freedom" (Estés, 1995, p. 236). By the "too-tame life" Estés means living with the rich old lady, who is depicted as "the rigid keeper of collective tradition, an enforcer of the unquestioned status quo" (Estés, 1995, 244), and being well-mannered or, more generally, conforming to the rules set by the community or culture. More importantly, it also means yielding to the temptation of an easy and pleasant life while actually ignoring one's own true needs and desires. As a result, the woman tries to compensate for her passivity, submissiveness, "overdomestication," or loss of self-expression and might become involved in "excessive behaviors" (Estés, 1995, p.248). In the story "excess" is represented by dancing without control and it can stand for all types of addictions or obsessions such as "chronic negative thinking, poor relationships, abusive situations, drugs or alcohol" (Estés, 1995, p. 268). They all eventually lead to trauma and self-destruction. Generally speaking, for Estes the red shoes represent unconscious 
destructive patterns of behaviour, injured instincts and distorted perception of the surrounding world.

\section{Conclusion}

All in all, it can be concluded that Estés's interpretations of the tales centre around the themes of initiation rites, the gaining or awakening of intuition as well as the gaining and loss of natural instincts. All these elements seem to be essential in forming the true female self which is free to make independent choices, strong enough to fight obstacles and ready to develop as well as to bear the consequences of its own behaviours. Interestingly, this wildish nature of the female self is common for women regardless of their cultural backgrounds as suggested by the fact that the tales are of various origins (German, Russian, Danish) and multiple versions of the same tales have been told in different countries. Furthermore, with her feminist-oriented approach, Estés draws our attention to the fact that in oral tradition these were usually women who were story-tellers while the process of writing the folk tales down was taken over by men, which considerably influenced the way the characters were presented, and among them many female characters. Zipes notices: "The voices of the nonliterate tellers were submerged, and since women in most cases were not allowed to be scribes, the tales were scripted according to male dictates or fantasies, even though they may have been told by women. Put crudely, one could say that the literary appropriation of the oral wonder tales served the hegemonic interests of males within the upper classes of particular communities and societies" (Zipes, 2007, p. 7). Thus Estés's work seems to be of special importance as it brings the female perspective back to light and appreciates what may have been stereotypically perceived as negative female features such as curiosity, relying on instincts and intuition or disobedience. Additionally, it could inspire further literary research as the motifs and symbols appearing in fairy tales as well as presented behaviour patterns discussed by the author can be also found in more contemporary literature.

\section{References:}

1. Davidson, H. (2006). Sex and Sin: The Magic of Red Shoes. In: P. McNeil, G. Riello (ed.), Shoes: A History from Sandals to Sneakers (p. 272-288). Oxford: Berg Publishers.

2. Estés, C.P. (1995). Women Who Run With the Wolves: Myths and Stories of the Wild Woman Archetype. New York: Random House.

3. Gary, J., El-Shamy, H. (ed.) (2005). Archetypes and Motifs in Folklore and Literature: A Handbook. New York: M.E. Sharpe, Inc.

4. Hermansson, C. E. (2009). Bluebeard: A Reader's Guide to the English Tradition. Jackson: University Press of Mississippi. https://doi.org/10.14325/mississippi/9781604732306.001.0001

5. Meletinsky, E. M. (1998). The Poetics of Myth. New York: Routledge.

6. Stevens, A. (2002). Archetype Revisited: An Updated Natural History of the Self. London: Brunner-Routledge.

7. Tatar, M. (1987). The Hard Facts of the Grimms' Fairy Tales. Princeton: Princeton University Press.

8. Tatar, M. (ed.) (2002). The Annotated Classic Fairy Tales. New York: W. W. Norton \& Company, Inc.

9. Zipes, J. (ed.) (2000). The Oxford Companion to Fairy Tales. Oxford: Oxford University Press.

10. Zipes, J. (2007). When Dreams Came True: Classical Fairy Tales and Their Tradition. New York: Routledge.

11. Zipes, J. (2012). The Irresistible Fairy Tale: The Cultural and Social History of a Genre. Princeton: Princeton University Press. 